\title{
CircRNAs as potential biomarkers for the clinicopathology and prognosis of glioma patients: a meta-analysis
}

Xiangqian Ding ${ }^{1 \dagger}$, Luyao Yang ${ }^{2 \dagger}$, Xin Geng ${ }^{1}$, Yanghong Zou' ${ }^{1}$ Zhigang Wang ${ }^{1}$, Yao Li', Renli Qi ${ }^{1}$, Wei Wang ${ }^{1}$, Jinghui $\mathrm{Li}^{1,3^{*}}$ and Hualin $\mathrm{Yu}^{1 *}$

\begin{abstract}
Background: An increasing number of studies have reported circular RNAs (circRNAs) as new potential biomarkers for the prognosis of gliomas. However, the overall prognostic value of circRNAs for glioma remains unclear. Therefore, this study is the first comprehensive evaluation of the clinicopathological and prognostic value of dysregulated circRNAs in the treatment of glioma patients.

Methods: We systematically reviewed the online databases of PubMed, Web of Science, EMBASE, and Cochrane Library to identify studies that explored the relationship between circRNA expression and clinicopathological and prognostic factors in glioma through April 11,2020. The quality of the included studies was evaluated by the Newcastle-Ottawa Scale (NOS) checklists. Clinicopathological features were assessed by pooled odds ratios (ORs) and 95\% confidence intervals (Cls), and overall survival (OS) was assessed by hazard ratios (HRs) and 95\% Cls.

Results: Twenty-four eligible studies, including 22 studies of clinicopathological features, 1 diagnostic study, and 18 studies of prognosis, that included a total of 1390 patients were ultimately included in this study. Meta-analysis showed that highly expressed oncogenic circRNAs were significantly related to poor clinicopathological features (age: $P=0.026$; tumor size: $P \leq 0.001$; tumor grade: $P \leq 0.001$; KPS: $P=0.012)$ and worse overall survival $(\mathrm{OS})(H R=$ 2.01, 95\% Cl: 1.61-2.50, $P \leq 0.001)$. Moreover, we found that highly expressed tumor-suppressor circRNAs were related to better clinicopathological features (gender: $P=0.042$; age: $P=0.014$; tumor size: $P=0.022$; tumor grade: $P \leq 0.001)$ and longer $\mathrm{OS}(\mathrm{HR}=2.70,95 \% \mathrm{Cl}: 1.82-3.99, P \leq 0.001)$.
\end{abstract}

Conclusions: In conclusion, there is a significant correlation between the dysregulated expression of circRNAs and the clinicopathology and prognosis of glioma patients.

Keywords: Circular RNA, Glioma, Prognosis, Clinicopathology, Meta-analysis

\footnotetext{
*Correspondence: km_ljh@126.com; lijh@ydyy.cn; yuhualin308@126.com; xuhl@ydyy.cn

${ }^{+}$Xiangqian Ding and Luyao Yang contributed equally to this work.

${ }^{1}$ Second Department of Neurosurgery, Kunming Medical University First Affiliated Hospital, 650032, No.295, Xichang road, Kunming, Yunnan, China Full list of author information is available at the end of the article
}

(c) The Author(s). 2020 Open Access This article is licensed under a Creative Commons Attribution 4.0 International License, which permits use, sharing, adaptation, distribution and reproduction in any medium or format, as long as you give appropriate credit to the original author(s) and the source, provide a link to the Creative Commons licence, and indicate if changes were made. The images or other third party material in this article are included in the article's Creative Commons licence, unless indicated otherwise in a credit line to the material. If material is not included in the article's Creative Commons licence and your intended use is not permitted by statutory regulation or exceeds the permitted use, you will need to obtain permission directly from the copyright holder. To view a copy of this licence, visit http://creativecommons.org/licenses/by/4.0/ The Creative Commons Public Domain Dedication waiver (http://creativecommons.org/publicdomain/zero/1.0/) applies to the data made available in this article, unless otherwise stated in a credit line to the data. 


\section{Background}

Glioma is a type of primary central nervous system tumor that originates from glial cells, accounting for approximately $80 \%$ of intracranial malignancies [1]. In recent years, although much progress has been made in the field of glioma surgery, radiotherapy, chemotherapy, and targeted therapy, the therapeutic effect is still not ideal, and the average survival time of patients is only 12-14 months [2]. With the development of highthroughput sequencing technology, research on the molecular basis of cancer has advanced, but the pathogenesis and biomarkers of gliomas are still unclear [35]. To improve the clinical efficacy of treatment and to understand the pathogenesis of glioma more clearly, it is urgent to conduct further research on molecular markers related to glioma.

Circular RNA (circRNA) is a type of long-chain noncoding RNA without a $5^{\prime}$ cap and $3^{\prime}$ polyadenylated tail structure that is joined by a covalent bond structure after special pre-RNAs undergo backsplicing. CircRNA is widely present in different species and a variety of human cells and has the characteristics of structural stability, high conservatism, complex regulation and tissue-specific expression [6]. Studies have shown that circRNA can act as a "molecular sponge" to adsorb microRNAs (miRNAs) to regulate gene expression, and can also play a role in directly regulating transcription and interfering with splicing mechanisms, so we believe that circRNA is closely related to the existence and development of cells like long non-coding RNAs [7-9].

Recently, the relationship between circRNAs and glioma prognosis has become the focus of research. For example, the high expression of hsa_circ_0013520 and hsa_circ_0004379 is related to poor prognosis in glioma patients and can be used as a novel prognostic biomarker for glioma [10]. However, single studies often have the disadvantages of being inaccurate and incomprehensive because of small sample sizes and the nature of being a single research project. Through searching, we did not find a meta-analysis about the prognostic value of circRNAs in gliomas. Therefore, we conducted a meta-analysis to explore the relationships of clinicopathological characteristics and prognosis with circRNA expression.

\section{Methods}

The project design, data analysis and reporting of the results of this study were strictly implemented in accordance with the Preferred Reporting Items for Systematic Reviews and Meta-analyses (PRISMA) statement guidelines [11]. We analyzed only summary data at the research level.

\section{Literature retrieval strategy}

We carefully reviewed the PubMed, EMBASE, Cochrane Library, and Web of Science databases for relevant articles that studied the clinical value, including the assessment of pathological features, diagnosis, and prognosis, of circRNA expression in glioma patients before April 11, 2020. We searched PubMed using the following strategy: ((("Glioma”[Mesh]) OR $((()((()(()($ Gliomas) OR Glial Cell Tumors) OR Glial Cell Tumor) OR Tumor, Glial Cell) OR Tumors, Glial Cell) OR Mixed Glioma) OR Glioma, Mixed) OR Gliomas, Mixed) OR Mixed Gliomas) OR Malignant Glioma) OR Glioma, Malignant) OR Gliomas, Malignant) OR Malignant Gliomas $))$ AND (("RNA, Circular"[Mesh]) OR (((()((()((circRNAs) OR Closed Circular RNA) OR Circular RNA, Closed) OR RNA, Closed Circular) OR Circular RNA) OR Circular RNAs) OR RNAs, Circular) OR circRNA) OR Circular Intronic RNA) OR Intronic RNA, Circular) OR Intronic RNA, Circular) OR ciRNA)). We also manually screened references for applicable articles.

\section{Eligibility criteria}

The inclusion criteria were articles that (a) studied the expression level of circRNA in clinical glioma patients and reported the relationship between the expression level and clinicopathological characteristics; (b) studied the circRNA concentration of a sample and reported sufficient data on the sample size, sensitivity and specificity; (c) studied the relationship between lncRNA expression levels and overall survival (OS), and provided hazard ratio (HR) values and 95\% confidence intervals (CIs), or Kaplan-Meier curves. Moreover, the exclusion criteria were (a) non-English articles; (b) studies not relevant to circRNA or glioma; (c) studies not conducted on humans; (d) studies in which the sample size was less than 30; (e) reviews, case reports, meeting records or letters; (f) studies without available data for analysis and whose authors could not be contacted.

\section{Quality assessment and data extraction}

The quality assessment of eligible studies was independently completed by two investigators (Xiangqian Ding and Luyao Yang) in accordance with the NewcastleOttawa Scale (NOS). Differences were finally agreed upon through negotiation. The highest NOS score was 9 , and the NOS score cut-off for high-quality studies was $\geq 6$.

Data extraction for eligible studies was also completed independently by two investigators (Xiangqian Ding and Luyao Yang) in accordance with standardized forms. The researchers reached an agreement through consultation. Contents of the standardized form covered the following information: (a) shared information: author, publication year, study region, circRNA type, tumor type, 
expression level of circRNAs, and assay methods; (b) clinicopathological features: sample size, cut-off definition, gender, age, tumor size, WHO grade, tumor location, and Karnofsky performance score (KPS); (c) diagnostic information: detected sample, sample size, sensitivity, specificity, area under the curve (AUC), and 95\% CI; and (d) prognostic information: sample size, cut-off definition, tumor stage, detected sample, high level, low level, survival analysis, HR, 95\% CI, high vs low expression, HR availability, analysis type, follow-up month, or data extracted from Kaplan-Meier curves [12].

\section{Statistical analysis}

We used STATA 14.0 software to perform statistical analysis of the extracted data. Clinicopathological parameters were evaluated using odds ratios (ORs) and 95\% CIs, and OS was evaluated using HRs and 95\% CIs. The heterogeneity of study was evaluated using chisquare test and $I^{2}$ statistics. When the $I^{2}$ value is $>50 \%$, the heterogeneity was considered significant, and the analysis was performed using a random-effect model; when the $I^{2}$ value was $<50 \%$, the heterogeneity was considered nonsignificant, and the analysis was performed using a fixed-effect model [13]. When $P$ was $<0.05$, the difference was considered statistically significant.

To evaluate the stability and reliability of the pooled effect size, we conducted a sensitivity analysis of the included prognostic-related studies. The studies were excluded one by one and the effects were combined to observe whether the results changed significantly. If there was no major change in the results, the sensitivity is low and the results are stable and reliable; on the contrary, if the difference between the merged results after the exclusion and the original results is large, the sensitivity is high and the stability of the results is low. The publication bias of the included studies was qualitatively tested by a funnel chart and quantitatively tested by Begg's and Egger's tests.

\section{Results}

\section{Literature search results}

Figure 1 shows the literature retrieval process and related results. We retrieved a total of 346 related studies, including 116 from PubMed, 121 from Embase, and 109 from Web of Science. We first excluded 194 duplicate studies and then excluded 78 unrelated studies after reading the titles and abstracts. Subsequently, after reviewing the fulltext of 74 studies, 50 irrelevant studies were excluded, including 36 studies without clinical data or insufficient data, 12 nonhuman studies, 1 comment, and 1 radiotherapy-related study. In summary, 24 eligible studies, including 22 studies of clinicopathological features [10, 14-34], 1 study of diagnostics [35], and 18 studies of prognosis [10, 14-28, 35, 36], including a total of 1390 glioma patients were ultimately included in this study.

\section{Study characteristics}

Table 1 and Table 2 show the features of eligible studies related to clinicopathology and prognosis, respectively.

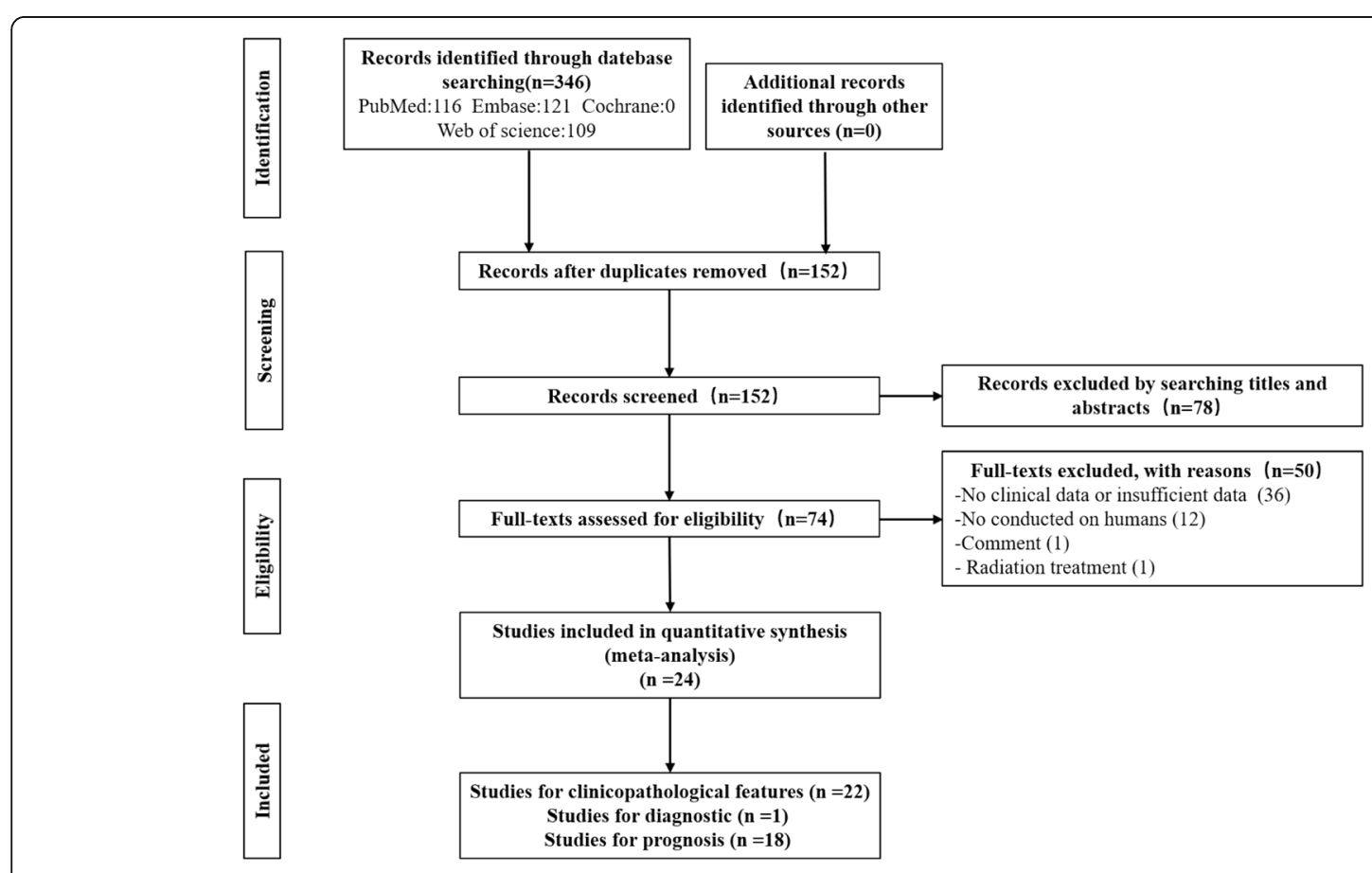

Fig. 1 Flowchart of the study selection process 
Table 1 The $p$ values summary of the association between circRNAs and clinicopathological features

\begin{tabular}{|c|c|c|c|c|c|c|c|c|c|c|c|c|c|c|}
\hline $\begin{array}{l}\text { Author } \\
\text { (ref.) year }\end{array}$ & Country & CircRNA & $\begin{array}{l}\text { Tumor } \\
\text { type }\end{array}$ & Expression & $\begin{array}{l}\text { Assay } \\
\text { methods }\end{array}$ & Case & $\begin{array}{l}\text { Cut-off } \\
\text { value }\end{array}$ & Gender & Age & $\begin{array}{l}\text { Tumor } \\
\text { size }(\mathrm{cm})\end{array}$ & $\begin{array}{l}\text { WHO } \\
\text { grade }\end{array}$ & $\begin{array}{l}\text { Tumor } \\
\text { location }\end{array}$ & KPS & $\begin{array}{l}\text { Family } \\
\text { history }\end{array}$ \\
\hline $\begin{array}{l}\text { Zhu [14] } \\
2017\end{array}$ & China & circBRAF & glioma & $\begin{array}{l}\text { down- } \\
\text { regulation }\end{array}$ & qRT-PCR & 68 & NA & 0.331 & 0.011 & $1(5)$ & $<0.001$ & NA & 0.429 & NA \\
\hline $\begin{array}{l}\text { Wang [15] } \\
2018\end{array}$ & China & $\begin{array}{l}\text { Circ- } \\
0001649\end{array}$ & glioma & $\begin{array}{l}\text { down- } \\
\text { regulation }\end{array}$ & qRT-PCR & 64 & NA & 0.196 & 0.803 & $0.002(3)$ & 0.023 & 0.297 & NA & 0.474 \\
\hline $\begin{array}{l}\text { Qu [16] } \\
2019\end{array}$ & China & $\begin{array}{l}\text { circ- } \\
0079593\end{array}$ & glioma & $\begin{array}{l}\text { up- } \\
\text { regulation }\end{array}$ & qRT-PCR & 60 & mean & 0.789 & 0.17 & $0.009(3)$ & 0.002 & 0.604 & NA & 0.506 \\
\hline $\begin{array}{l}\text { Lv [17] } \\
2020\end{array}$ & China & $\begin{array}{l}\text { Circ- } \\
\text { EPB41L5 }\end{array}$ & GBM & $\begin{array}{l}\text { down- } \\
\text { regulation }\end{array}$ & qRT-PCR & 45 & median & 0.449 & 0.026 & $0.42\left(10 \mathrm{~cm}^{3}\right)$ & NA & NA & 0.279 & NA \\
\hline $\begin{array}{l}\text { Duan [18] } \\
2018\end{array}$ & China & $\begin{array}{l}\text { circ- } \\
0074362\end{array}$ & glioma & $\begin{array}{l}\text { up- } \\
\text { regulation }\end{array}$ & qRT-PCR & 62 & NA & 0.806 & 0.074 & $0.04(4)$ & 0.005 & NA & NA & NA \\
\hline $\begin{array}{l}\text { Zhang [19] } \\
2019\end{array}$ & China & $\begin{array}{l}\text { circ- } \\
0029426\end{array}$ & glioma & $\begin{array}{l}\text { up- } \\
\text { regulation }\end{array}$ & qRT-PCR & 59 & mean & 0.601 & 0.415 & $0.033(3)$ & 0.036 & 0.105 & NA & 0.741 \\
\hline $\begin{array}{l}\text { Yang [20] } \\
2019\end{array}$ & China & $\begin{array}{l}\text { circ- } \\
\text { POSTN }\end{array}$ & glioma & $\begin{array}{l}\text { up- } \\
\text { regulation }\end{array}$ & qRT-PCR & 58 & mean & 0.787 & 0.77 & $0.033(3)$ & 0.034 & 0.793 & NA & 0.505 \\
\hline $\begin{array}{l}\text { Yang [21] } \\
2019\end{array}$ & China & $\begin{array}{l}\text { circ- } \\
0034642\end{array}$ & glioma & $\begin{array}{l}\text { up- } \\
\text { regulation }\end{array}$ & qRT-PCR & 68 & mean & 0.312 & 0.201 & $0.014(3)$ & 0.003 & 0.219 & NA & 0.356 \\
\hline $\begin{array}{l}\text { Wang [22] } \\
2019\end{array}$ & China & $\begin{array}{l}\text { circ- } \\
0005198\end{array}$ & glioma & $\begin{array}{l}\text { up- } \\
\text { regulation }\end{array}$ & qRT-PCR & 44 & $\begin{array}{l}\text { fold } \\
\text { change }\end{array}$ & 0.51 & 0.698 & $0.014(3)$ & 0.012 & 0.543 & NA & 1 \\
\hline $\begin{array}{l}\text { Meng [23] } \\
2019\end{array}$ & China & $\begin{array}{l}\text { circ- } \\
\text { SCAF11 }\end{array}$ & glioma & $\begin{array}{l}\text { up- } \\
\text { regulation }\end{array}$ & qRT-PCR & 40 & NA & 0.612 & 0.153 & $0.015(3)$ & 0.178 & NA & 0.317 & NA \\
\hline $\begin{array}{l}\text { Lyu [10] } \\
2020\end{array}$ & China & $\begin{array}{l}\text { circ- } \\
0013520\end{array}$ & glioma & $\begin{array}{l}\text { up- } \\
\text { regulation }\end{array}$ & qRT-PCR & 92 & mean & 0.747 & 0.511 & $<0.001(3)$ & 0.004 & NA & 0.008 & NA \\
\hline $\begin{array}{l}\text { Lyu [10] } \\
2020\end{array}$ & China & $\begin{array}{l}\text { circ- } \\
0004379\end{array}$ & glioma & $\begin{array}{l}\text { up- } \\
\text { regulation }\end{array}$ & qRT-PCR & 92 & mean & 0.799 & 0.641 & $<0.001(3)$ & 0.005 & NA & 0.006 & NA \\
\hline $\begin{array}{l}\text { Lu [24] } \\
2019\end{array}$ & China & $\begin{array}{l}\text { circ- } \\
0001730\end{array}$ & glioma & $\begin{array}{l}\text { up- } \\
\text { regulation }\end{array}$ & qRT-PCR & 99 & NA & 0.132 & 0.611 & NA & 0.004 & NA & NA & NA \\
\hline $\begin{array}{l}\text { Liu [25] } \\
2020\end{array}$ & China & $\begin{array}{l}\text { circ- } \\
\text { CDC45 }\end{array}$ & glioma & $\begin{array}{l}\text { up- } \\
\text { regulation }\end{array}$ & qRT-PCR & 50 & median & 0.561 & 0.321 & $0.016(3)$ & 0.01 & 0.571 & NA & 0.496 \\
\hline $\begin{array}{l}\text { Ding [26] } \\
2019\end{array}$ & China & $\begin{array}{l}\text { circ- } \\
\text { NFIX }\end{array}$ & glioma & $\begin{array}{l}\text { up- } \\
\text { regulation }\end{array}$ & qRT-PCR & 64 & NA & 0.4363 & 0.765 & $0.0262(3)$ & 0.0177 & NA & NA & NA \\
\hline $\begin{array}{l}\text { Chen [27] } \\
2018\end{array}$ & China & $\begin{array}{l}\text { Circ- } \\
0000177\end{array}$ & glioma & $\begin{array}{l}\text { up- } \\
\text { regulation }\end{array}$ & qRT-PCR & 62 & NA & 0.451 & 0.198 & $0.01(4)$ & 0.02 & NA & NA & NA \\
\hline $\begin{array}{l}\text { Chen [28] } \\
2020\end{array}$ & China & $\begin{array}{l}\text { circ- } \\
0074026\end{array}$ & glioma & $\begin{array}{l}\text { up- } \\
\text { regulation }\end{array}$ & qRT-PCR & 60 & mean & 0.795 & 0.125 & $0.001(3)$ & 0.017 & 0.288 & NA & 0.731 \\
\hline $\begin{array}{l}\text { Zuo [29] } \\
2019\end{array}$ & China & $\begin{array}{l}\text { circ- } \\
\text { SMAD7 }\end{array}$ & glioma & $\begin{array}{l}\text { up- } \\
\text { regulation }\end{array}$ & qRT-PCR & 46 & NA & 0.309 & 0.978 & NA & 0.014 & NA & 0.0002 & NA \\
\hline $\begin{array}{l}\text { Zhan [30] } \\
2019\end{array}$ & China & $\begin{array}{l}\text { circ- } \\
\text { PITX1 }\end{array}$ & glioma & $\begin{array}{l}\text { up- } \\
\text { regulation }\end{array}$ & qRT-PCR & 52 & median & 0.765 & 0.541 & $0.023(3)$ & 0.025 & 0.406 & NA & 0.499 \\
\hline $\begin{array}{l}\text { Xie [31] } \\
2018\end{array}$ & China & $\begin{array}{l}\text { circ- } \\
0012129\end{array}$ & glioma & $\begin{array}{l}\text { up- } \\
\text { regulation }\end{array}$ & qRT-PCR & 31 & NA & 0.578 & 0.551 & NA & 0.014 & NA & NA & NA \\
\hline $\begin{array}{l}\text { Qian [32] } \\
2019\end{array}$ & China & $\begin{array}{l}\text { circ- } \\
0074027\end{array}$ & glioma & $\begin{array}{l}\text { up- } \\
\text { regulation }\end{array}$ & qRT-PCR & 50 & median & 0.529 & 0.345 & $0.045(3)$ & 0.021 & 0.158 & NA & 0.479 \\
\hline $\begin{array}{l}\text { Liu [33] } \\
2019\end{array}$ & China & $\begin{array}{l}\text { circ- } \\
001350\end{array}$ & glioma & $\begin{array}{l}\text { up- } \\
\text { regulation }\end{array}$ & qRT-PCR & 53 & mean & 0.266 & 0.76 & $0.013(3)$ & 0.029 & 0.588 & NA & 0.392 \\
\hline $\begin{array}{l}\text { He [34] } \\
2020\end{array}$ & China & $\begin{array}{l}\text { circ- } \\
\text { MAPK4 }\end{array}$ & glioma & $\begin{array}{l}\text { up- } \\
\text { regulation }\end{array}$ & qRT-PCR & 30 & NA & 0.919 & 0.855 & $0.513(3)$ & 0.044 & NA & NA & NA \\
\hline
\end{tabular}

qRT-PCR quantitative reverse transcription-polymerase chain reaction, NA not available, GBM glioblastoma multiforme

All the samples from the 24 studies were pathologically confirmed as gliomas, and all came from hospitals in China. The publication years ranged from 2017 to 2020 . The minimum sample size was 31 cases, and the maximum sample size was 99 cases. In addition, the expression levels of all circRNAs were measured using quantitative real-time polymerase chain reaction (qRTPCR). The upregulation of 21 circRNAs was considered to have tumor-promoting effects, and the downregulation of 4 circRNAs was considered to have tumor- 


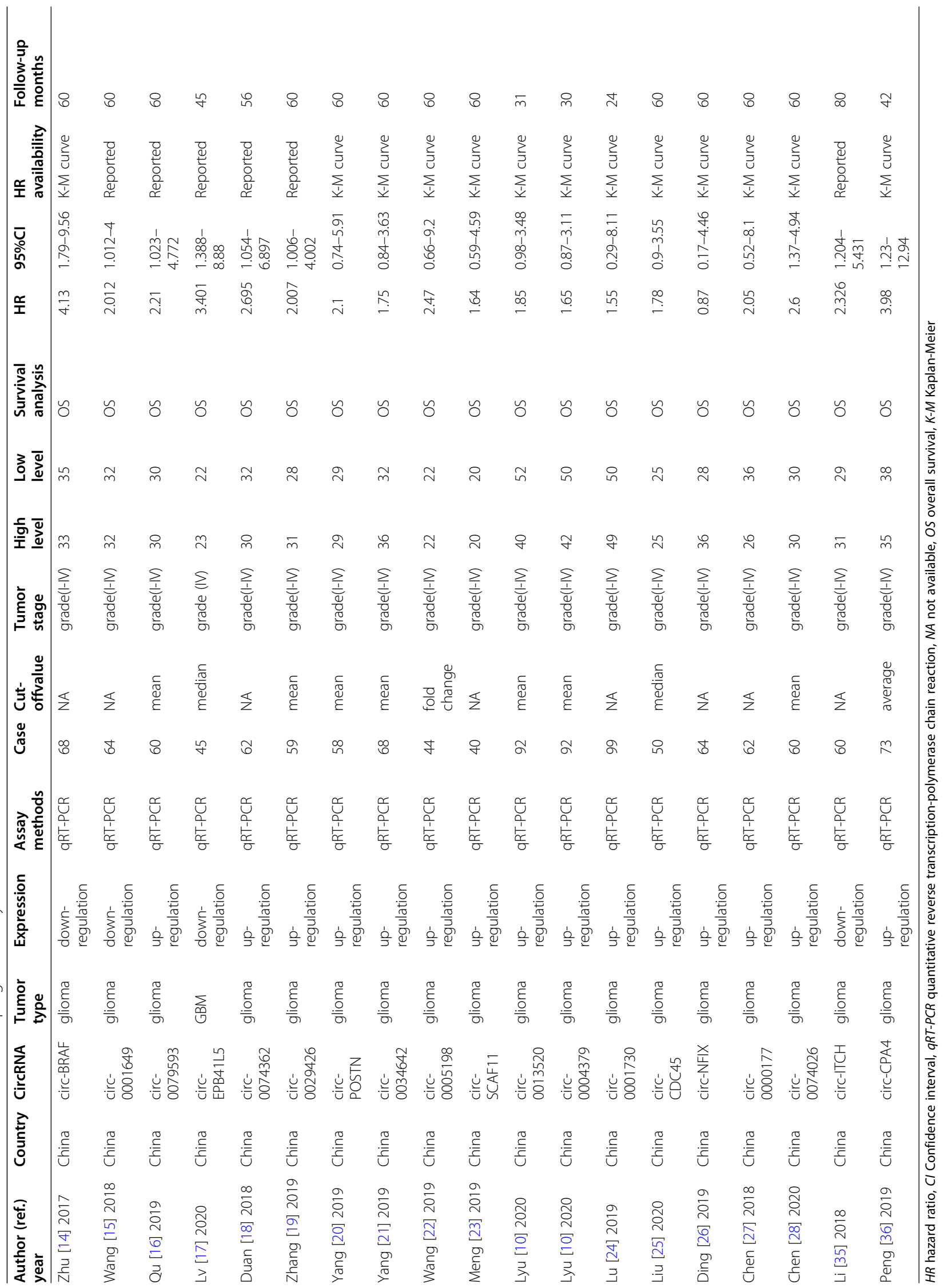


suppressing effects. The follow-up time ranged from 24 months to 80 months. Only one study reported the diagnostic sensitivity, specificity, and AUC data, so we did not perform a meta-analysis related to the diagnosis (Table S1). The included studies were all high-quality studies with NOS scores $\geq 6$ (Table S2).

\section{Clinicopathological features}

Twenty-three circRNAs were reported in the 22 included studies related to clinicopathological features. Upregulation of 20 circRNAs was considered to have tumor-promoting effects, and downregulation of 3 circRNAs was considered to be have tumor-suppressing effects. Table 3 shows the meta-analysis results of circRNAs and clinical features of glioma patients. High expression of oncogenic circRNAs was significantly related to poor clinicopathological features (age: $\mathrm{OR}=$ 1.32, 95\% CI: $1.03-1.68$; tumor size: $\mathrm{OR}=3.48,95 \%$ CI: 2.61-4.63; tumor grade: $\mathrm{OR}=4.24,95 \% \mathrm{CI}$ : $3.26-5.52$; $\mathrm{KPS}: \mathrm{OR}=0.21,95 \% \mathrm{CI}$ : 0.06-0.71). In addition, high expression of tumor-suppressor circRNAs was significantly related to better clinicopathological features (gender: $\mathrm{OR}=1.9,95 \% \mathrm{CI}: 1.02-3.51$; age: $\mathrm{OR}=0.46,95 \% \mathrm{CI}$ : 0.15-1.39; tumor size: $\mathrm{OR}=0.49,95 \%$ CI: $0.26-0.9$; tumor grade: $\mathrm{OR}=0.12,95 \% \mathrm{CI}: 0.05-0.27$ ), and other clinicopathological features (tumor location, KPS, and family history of cancer) had no significant relationships.

\section{Prognosis}

The 18 included studies related to prognosis reported date on 19 circRNAs and 1220 glioma patients. Figure 2 shows the meta-analysis results of the relationship between circRNAs and the OS of glioma patients. The results showed that high expression of oncogenic circRNAs had a significant correlation with poor prognosis (OS: $\mathrm{HR}=2.01,95 \% \mathrm{CI}: 1.61-2.50, P<0.001)$. The heterogeneity was not notable $\left(I^{2}=0.0 \%, P=0.993\right)$, and we used a fixed-effect model. Moreover, high expression of tumor-suppressor circRNAs had a significant correlation with improved prognosis (OS: $\mathrm{HR}=2.70,95 \% \mathrm{CI}$ : $1.82-3.99, \quad P<0.001)$. Due to the lack of notable heterogeneity $\left(I^{2}=0.0 \%, P=0.977\right)$, we used a fixedeffect model.

\section{Sensitivity analysis and publication bias}

The sensitivity analysis results showed that no single study had a significant effect on pooled HRs, indicating that our research results have strong reliability (Fig. 3a). As shown in Fig. 3b, we found no indication of publication bias according to the funnel chart. The result of Begg's test is shown in Fig. 3c $(P=0.624)$, and the result of Egger's test is shown in Fig. $3 \mathrm{~d}(P=0.857)$. Therefore, our research can exclude the possibility of publication bias.

\section{Discussion}

With the rapid development and wide application of bioinformatics and high-throughput sequencing technology, the role of non-coding RNA has been extensively studied in various diseases. Among them, the mechanism of action of long non-coding RNA has been basically clear: in terms of epigenetic and transcriptional regulation, lncRNAs mainly complete functions by interacting with chromatin modification factors and transcription factors; in terms of post-transcriptional regulation, lncRNAs mainly act by adsorbing miRNAs to regulate miRNAsmediated cellular processes [9]. However, the mechanism of circRNA needs further study. Studies have shown that circRNAs not only regulate the expression of downstream genes by adsorbing miRNAs, but also directly regulate transcription and interfere with the splicing process [37]. The 24 papers included in this article include 25 circRNAs, 20 of which mediate cellular processes by adsorbing miRNAs. In view of the important role of circRNA in cell growth and development, we believe that circRNA has strong application prospects like IncRNA.

Through the PubMed search, we found a large number of studies on the relationship between the expression of a single circRNA and the prognosis of glioma, but no meta- analysis of circRNA expression and the prognosis of glioma patients was found [10, 14-28, 35, 36]. This

Table 3 Meta-analysis results for circRNAs expression with clinicopathological features

\begin{tabular}{|c|c|c|c|c|}
\hline & \multicolumn{2}{|l|}{ Tumor promoter } & \multicolumn{2}{|l|}{ Tumor suppressor } \\
\hline & OR $(95 \% \mathrm{Cl})$ & $P$ value & OR $(95 \% \mathrm{Cl})$ & $P$ value \\
\hline Gender (M/W) & $1.25(0.99-1.58)$ & 0.061 & $1.9(1.02-3.51)$ & 0.042 \\
\hline Age & $1.32(1.03-1.68)$ & 0.026 & $0.46(0.15-1.39)$ & 0.014 \\
\hline Tumor size & $3.48(2.61-4.63)$ & 0.000 & $0.49(0.26-0.9)$ & 0.022 \\
\hline Tumor grade $(I I I+I V / I+I I)$ & $4.24(3.26-5.52)$ & 0.000 & $0.12(0.05-0.27)$ & 0.000 \\
\hline Tumor location (Supra/Infra) & $1.22(0.87-1.70)$ & 0.248 & $1.99(0.7-5.62)$ & 0.195 \\
\hline KPS & $0.21(0.06-0.71)$ & 0.012 & $0.98(0.19-4.99)$ & 0.981 \\
\hline Family history of cancer (Y/N) & $1.43(0.92-2.21)$ & 0.108 & $0.45(0.1-1.98)$ & 0.289 \\
\hline
\end{tabular}

$O R$ odds ratio, $\mathrm{Cl}$ confidence interval, $M$ men, $W$ women, $Y$ yes, $N$ no, the results are in bold if $p<0.05$ 


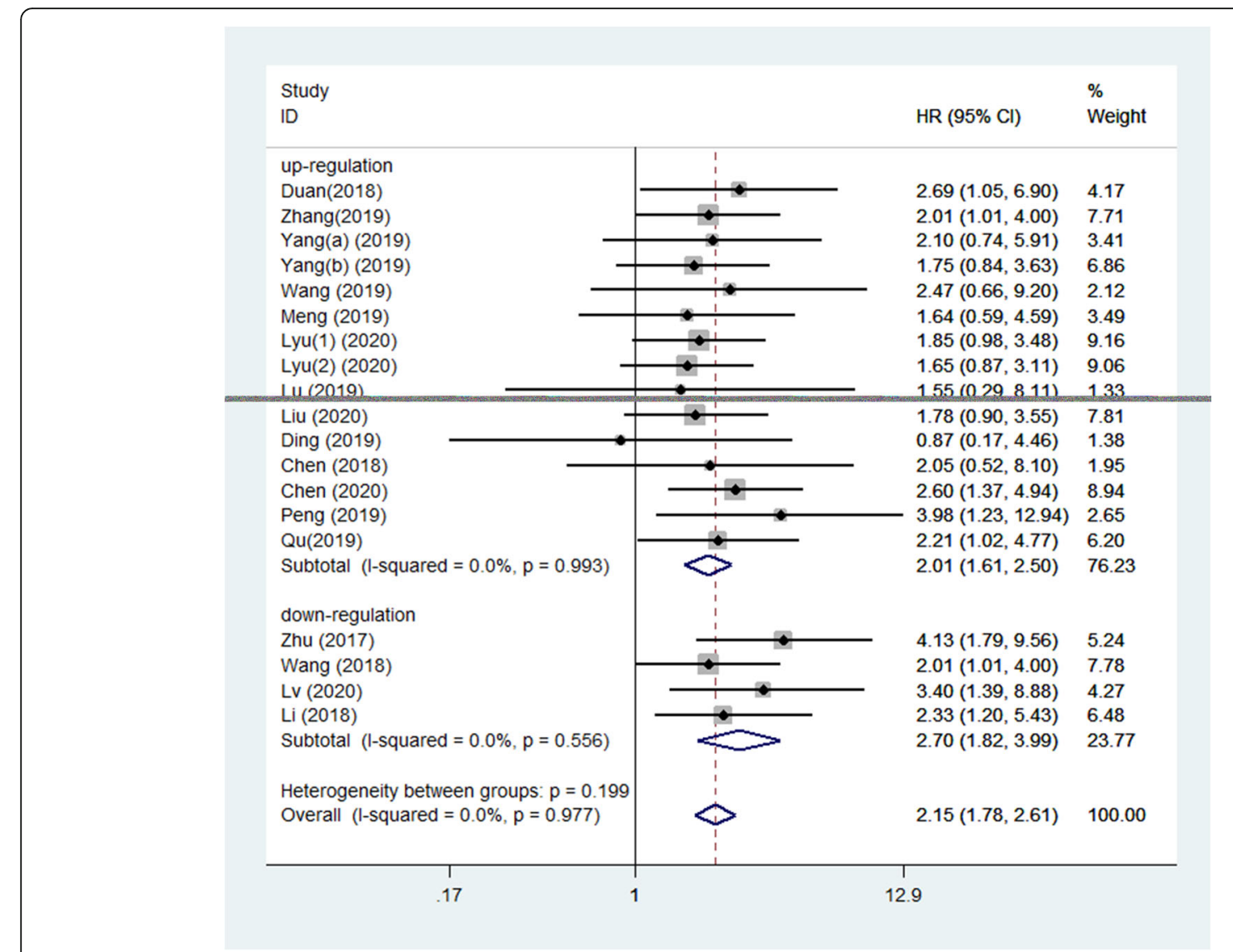

Fig. 2 Forest plots for overall survival according to the type of upregulated circRNAs and downregulated circRNAs in glioma patients

study evaluates for the first time the important relationship between circRNA expression disorders and the clinicopathological and prognostic features of glioma patients. Our study included 24 eligible studies that included a total of 1390 glioma patients. By comparing the expression levels of circRNAs with the levels in normal tissues, we divided circRNAs into two groups: carcinogenic tumor promoters and tumor suppressors.

The meta-analysis showed that the expression levels of circRNAs are significantly correlated with the clinicopathological features of glioma patients. High expression of tumor-promoter circRNAs is significantly associated with poor clinicopathological features, including age, tumor size, tumor grade, and KPS. In addition, high expression of tumor-suppressor circRNAs was significantly associated with better clinicopathological features, including gender, age, tumor size, and tumor grade. In summary, dysregulated expression of circRNAs is related to the occurrence and development of glioma, which is consistent with the current mainstream views [38].

Many single studies have reported that dysregulated expression of circRNAs is a poor prognostic factor in glioma patients based on multivariate Cox regression analysis $[15-19,35]$. After a subgroup analysis, we found that circRNAs with different expression levels have different prognostic features in gliomas. Carcinogenic circRNAs are associated with a shorter OS time in glioma patients, and tumor-suppressor circRNAs are associated with a longer OS time in glioma patients. Moreover, heterogeneity testing, sensitivity analysis, and publication bias increase the reliability of the results. Therefore, circRNAs have significant clinical applications as oncogenes or tumor suppressors.

Related studies have also reported that circRNAs have great potential as novel biomarkers for glioma prognosis [38]. CircRNAs have obvious advantages as a prognostic biomarker coupled with their unique characteristics: (a) circRNAs have a covalent, closed, continuous circular structure, which is more conservative and stable than linear RNA; (b) circRNAs are widely present in eukaryotic cells and have high expression levels in cells, tissues, and body fluids; (c) compared with traditional biomarkers, circRNAs are more specific in terms of tissue expression [39, 40]. In summary, these characteristics also promote circRNA to act as valuable 

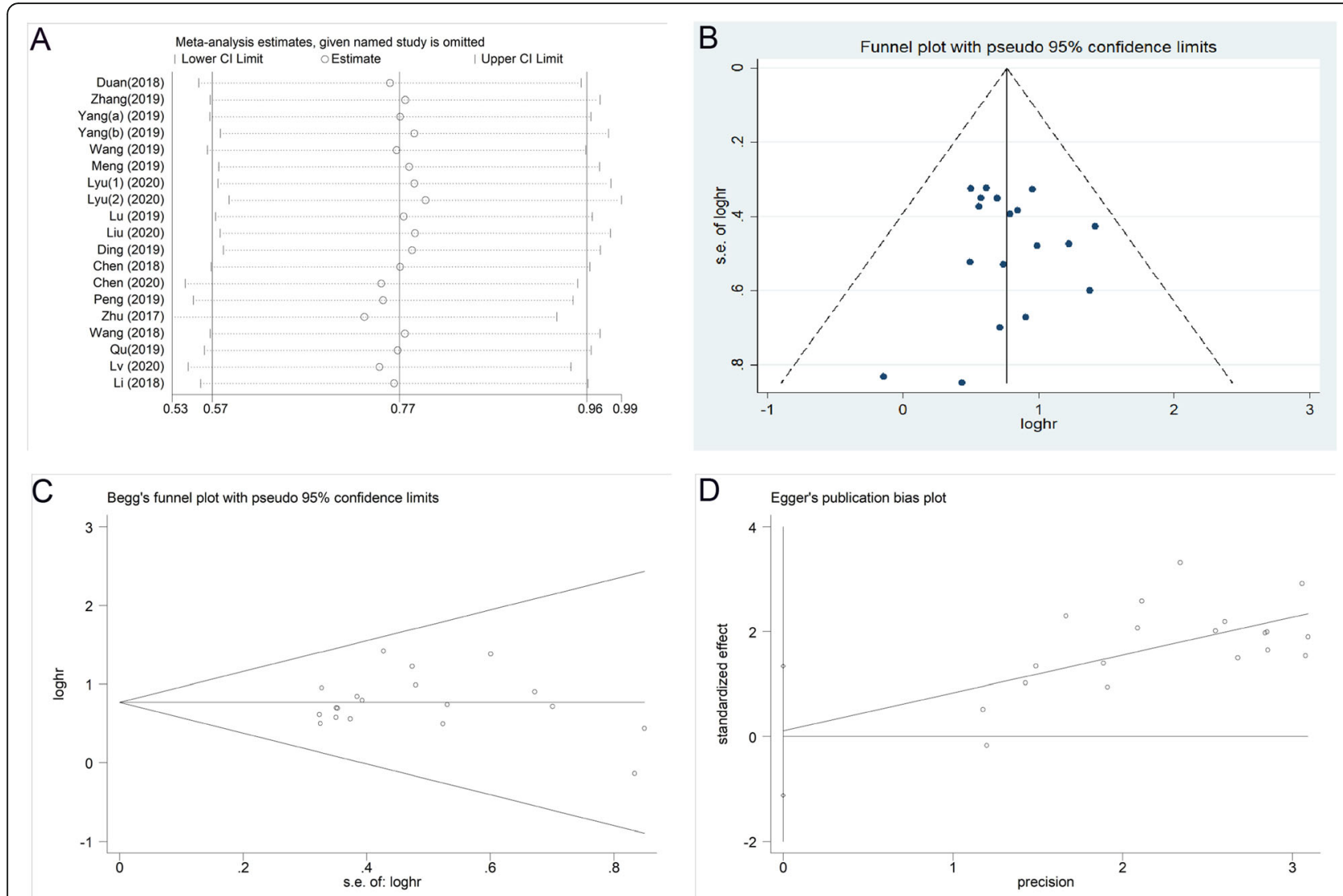

Fig. 3 Sensitivity analysis and publication bias of the meta-analysis of circRNAs and the prognosis of patients with glioma. a Sensitivity analysis plot; b Funnel plot; c Begg's funnel plot; d Egger's funnel plot

biomarkers for diagnosis, prognosis as well as therapeutic evaluation of glioma.

However, this study still has several limitations: (a) All eligible studies included different circRNAs, and we could not perform subgroup analysis on different circRNAs; (b) All the samples included in the study were from hospitals in China, and more studies in other regions are needed; and (c) For some studies that did not report a clear HR value, we extracted the HR value from the K-M curve, which may increase the potential for bias. Therefore, many prospective studies with larger sample sizes, more centers, and deeper exploration of functional mechanisms are needed.

\section{Conclusions}

In conclusion, there is a significant correlation between the dysregulated expression of circRNAs and the clinicopathology and prognosis of glioma patients. Therefore, circRNAs have the potential to become novel biomarkers and therapeutic targets for the treatment of glioma.

\section{Supplementary information}

Supplementary information accompanies this paper at https://doi.org/10. 1186/s12885-020-07446-4.

Additional file 1. Table S1. Main features of studies included in the diagnosis analysis.

Additional file 2. Table S2. Quality assessment of eligible studies (Newcastle-Ottawa Scale).

\section{Abbreviations}

AUC: Area under the curve; Cl: Confidence interval; CircRNA: Circular RNA; HR: Hazard ratio; MiRNAs: MicroRNAs; NOS: Newcastle-Ottawa Scale;

ORs: Odds ratios; OS: Overall survival; QRT-PCR: Quantitative real-time polymerase chain reaction

\section{Acknowledgements}

We would like to acknowledge the STATA 14.0 software, PubMed, EMBASE, Cochrane Library, and Web of Science databases.

\section{Authors' contributions}

$X Q D$, JHL and HLY designed the study; XQD and LYY collected the literature and conducted the analysis of pooled data; LYY helped to draft the manuscript; XQD, JHL and LYY wrote the manuscript; GX, YHZ, ZGW, YL, RLQ, and $W W$ proofread, revised and final approved the manuscript; all authors have approved the version to be published. 


\section{Funding}

This work was supported by grants from the Yunnan Provincial Science and Technology Department grant number 2017FE467(- 032) (funded by GX, proofread and revised the manuscript) and 2017FE467(- 033) (funded by $\mathrm{JHL}$, designed and wrote the manuscript), the Yunnan Provincial Department of Education (grant number K1321969, funded by HLY, designed, revised and final approved the manuscript), and Kunming Medical University Graduate Innovation Funding (grant number 2020D004, funded by XQD, designed and wrote the manuscript)

\section{Availability of data and materials}

The data that support the findings of this study are available on request from the corresponding author.

\section{Ethics approval and consent to participate}

Not applicable.

\section{Consent for publication}

Not applicable.

\section{Competing interests}

All authors have no competing interests to declare.

\section{Author details}

${ }^{1}$ Second Department of Neurosurgery, Kunming Medical University First Affiliated Hospital, 650032, No.295, Xichang road, Kunming, Yunnan, China. ${ }^{2}$ Department of Anesthesiology, Liaocheng people's hospital, LiaoCheng, Shandong, China. ${ }^{3}$ Graduate School of Kunming Medical University, 650500, No.1168, Kunming, Yunnan, China.

\section{Received: 5 June 2020 Accepted: 21 September 2020} Published online: 15 October 2020

\section{References}

1. Goodenberger ML, Jenkins RB. Genetics of adult glioma. Cancer Genet. 2012;205(12):613-21.

2. Louis DN, Perry A, Reifenberger G, von Deimling A, Figarella-Branger D, Cavenee WK, Ohgaki H, Wiestler OD, Kleihues P, Ellison DW. The 2016 World Health Organization classification of tumors of the central nervous system: a summary. Acta Neuropathol. 2016;131(6):803-20.

3. Kamaraj B, Purohit R. Mutational analysis on membrane associated transporter protein (MATP) and their structural consequences in Oculocutaeous albinism type 4 (OCA4)-a molecular dynamics approach. J Cell Biochem. 2016;117(11):2608-19.

4. Comprehensive molecular characterization of gastric adenocarcinoma. Nature. 2014;513(7517):202-9.

5. Bhuvanalakshmi G, Gamit N, Patil M, Arfuso F, Sethi G, Dharmarajan A Kumar A, Warrier S. Stemness, Pluripotentiality, and Wnt Antagonism: sFRP4, a Wnt antagonist Mediates Pluripotency and Stemness in Glioblastoma. Cancers. 2018;11(1).

6. Li X, Yang L, Chen LL. The biogenesis, functions, and challenges of circular RNAs. Mol Cell. 2018;71(3):428-42.

7. Shang Q, Yang Z, Jia R, Ge S. The novel roles of circRNAs in human cancer. Mol Cancer. 2019;18(1):6.

8. Kristensen LS, Andersen MS, Stagsted LWW, Ebbesen KK, Hansen TB, Kjems J. The biogenesis, biology and characterization of circular RNAs. Nat Rev Genet. 2019;20(11):675-91.

9. Ma Z, Wang $Y$, Xin H, Wang L, Arfuso F, Dharmarajan A, Kumar A, Wang H, Tang F, Warrier S, et al. The expanding roles of long non-coding RNAs in the regulation of cancer stem cells. Int J Biochem Cell Biol. 2019;108:17-20.

10. Lyu XJ, Zhou L, Fan FJ, Dong Z. Genome-wide microarray analysis of circRNAs revealed novel biomarkers for Glioma treatment and their promoting effect on Glioma progression. OncoTargets Ther. 2020;13: 2739-45.

11. Moher D, Liberati A, Tetzlaff J, Altman D. Preferred reporting items for systematic reviews and meta-analyses: the PRISMA statement. PLoS Med. 2009;6(7):e1000097.

12. Tierney JF, Stewart LA, Ghersi D, Burdett S, Sydes MR. Practical methods for incorporating summary time-to-event data into meta-analysis. Trials. 2007;8:16.
13. Egger M, Davey Smith G, Schneider M, Minder C. Bias in meta-analysis detected by a simple, graphical test. BMJ (Clin Res Ed). 1997;315(7109): 629-34.

14. Zhu J, Ye J, Zhang L, Xia L, Hu H, Jiang H, Wan Z, Sheng F, Ma Y, Li W, et al. Differential expression of circular RNAs in Glioblastoma Multiforme and its correlation with prognosis. Transl Oncol. 2017;10(2):271-9.

15. Wang Y, Sui X, Zhao H, Cong L, Li Y, Xin T, Guo M, Hao W. Decreased circular RNA hsa_circ_0001649 predicts unfavorable prognosis in glioma and exerts oncogenic properties in vitro and in vivo. Gene. 2018;676: $117-22$.

16. Qu Y, Zhu J, Liu J, Qi L. Circular RNA circ_0079593 indicates a poor prognosis and facilitates cell growth and invasion by sponging miR-182 and miR-433 in glioma. J Cell Biochem. 2019;120(10):18005-13.

17. Lv T, Miao Y, Xu T, Sun W, Sang Y, Jia F, Zhang X. Circ-EPB41L5 regulates the host gene EPB41L5 via sponging miR-19a to repress glioblastoma tumorigenesis. Aging. 2020;12(1):318-39.

18. Duan X, Liu D, Wang Y, Chen Z. Circular RNA hsa_circ_0074362 promotes Glioma cell proliferation, migration, and invasion by attenuating the inhibition of miR-1236-3p on HOXB7 expression. DNA Cell Biol. 2018;37(11): 917-24.

19. Zhang GF, Sun WB, Zhu LF, Feng YP, Wu LH, Li TX. Overexpressed circ 0029426 in glioblastoma forecasts unfavorable prognosis and promotes cell progression by sponging miR-197. J Cell Biochem. 2019;120(6):10295-302.

20. Yang YM, Zhang Y, Chen B, Ding LL, Mu Z, Li YH. Elevation of circular RNA circ-POSTN facilitates cell growth and invasion by sponging miR-1205 in glioma. J Cell Biochem. 2019;120(10):16567-74.

21. Yang M, Li G, Fan L, Zhang G, Xu J, Zhang J. Circular RNA circ_0034642 elevates BATF3 expression and promotes cell proliferation and invasion through miR-1205 in glioma. Biochem Biophys Res Commun. 2019;508(3): 980-5.

22. Wang JD, Li J, Wang HW, Lv LT, Sun JH. Overexpression of circ_0005198 sponges miR-1294 to regulate cell proliferation, apoptosis, migration, and invasion in glioma. J Cell Biochem. 2019;120(9):15538-45.

23. Meng Q, Li S, Liu Y, Zhang ST, Jin JG, Zhang Y, Guo C, Liu B, Sun Y. Circular RNA circSCAF11 accelerates the Glioma tumorigenesis through the miR421/SP1/NEGFA Axis. Mol Ther Nucleic Acids. 2019;17:669-77.

24. Lu Y, Deng X, Xiao G, Zheng X, Ma L, Huang W. Circ0001730 promotes proliferation and invasion via the MIR-326/Wnt7B axis in glioma cells. Epigenomics. 2019;11(11):1335-52.

25. Liu J, Hou K, Ji H, Mi S, Yu G, Hu S, Wang J. Overexpression of circular RNA circ-CDC45 facilitates glioma cell progression by sponging miR-516b and miR-527 and predicts an adverse prognosis. J Cell Biochem. 2020;121(1): 690-7.

26. Ding $C Y$, Wu ZY, You HH, Ge HL, Zheng SF, Lin YX, Wu XY, Lin ZY, Kang DZ. CircNFIX promotes progression of glioma through regulating miR-378e/ RPN2 axis. J Exp Clin Cancer Res. 2019;38(1).

27. Chen Z, Duan X. Hsa-circ-0000177-miR-638-FZD7-Wnt signaling Cascade contributes to the malignant behaviors in Glioma. DNA Cell Biol. 2018;37(9): 791-7.

28. Chen M, Liu X, Xie P, Wang P, Liu M, Zhan Y, Wang H, Feng Y, Li Y. Circular RNA circ_0074026 indicates unfavorable prognosis for patients with glioma and facilitates oncogenesis of tumor cells by targeting miR-1304 to modulate ERBB4 expression. J Cell Physiol. 2020;235(5):4688-97.

29. Zuo C, Qian W, Huang C, Lu J. Circular RNA circ-SMAD7 promoted glioma cell proliferation and metastasis by upregulating PCNA. Eur Rev Med Pharmacol Sci. 2020;24(14):7542.

30. Zhan L, Mu Z, Yang M, Zhang T, Li H, Qian L. Elevation of circ-PITX1 upregulates interleukin 17 receptor $D$ expression via sponging miR-518a-5p and facilitates cell progression in glioma. J Cell Biochem. 2019;120(10): 16495-502.

31. Xie G. Circular RNA hsa-circ-0012129 promotes cell proliferation and invasion in 30 cases of human glioma and human glioma cell lines U373, A172, and SHG44, by targeting microRNA-661 (miR-661). Med Sci Monit. 2018:24:2497-507.

32. Qian L, Guan J, Wu Y, Wang Q. Upregulated circular RNA circ_0074027 promotes glioblastoma cell growth and invasion by regulating miR-518a5p/IL17RD signaling pathway. Biochem Biophys Res Commun. 2019;510(4): 515-9.

33. Liu Y, Ma C, Qin X, Yu H, Shen L, Jin H. Circular RNA circ_001350 regulates glioma cell proliferation, apoptosis, and metastatic properties by acting as a miRNA sponge. J Cell Biochem. 2019;120(9):15280-7. 
34. He J, Huang Z, He M, Liao J, Zhang Q, Wang S, Xie L, Ouyang L, Koeffler HP, Yin D, et al. Circular RNA MAPK4 (circ-MAPK4) inhibits cell apoptosis via MAPK signaling pathway by sponging miR-125a-3p in gliomas. Mol Cancer. 2020;19(1).

35. Li F, Ma K, Sun M, Shi S. Identification of the tumor-suppressive function of circular RNA ITCH in glioma cells through sponging miR-214 and promoting linear ITCH expression. Am J Transl Res. 2018;10(5):1373-86.

36. Peng H, Qin C, Zhang C, Su J, Xiao Q, Xiao Y, Xiao K, Liu Q. CircCPA4 acts as a prognostic factor and regulates the proliferation and metastasis of glioma. J Cell Mol Med. 2019;23(10):6658-65.

37. Hao Z, Hu S, Liu Z, Song W, Zhao Y, Li M. Circular RNAs: functions and prospects in Glioma. J Mol Neurosci. 2019;67(1):72-81.

38. Cheng J, Meng J, Zhu L, Peng Y. Exosomal noncoding RNAs in Glioma: biological functions and potential clinical applications. Mol Cancer. 2020; 19(1):66.

39. Lei M, Zheng G, Ning Q, Zheng J, Dong D. Translation and functional roles of circular RNAs in human cancer. Mol Cancer. 2020;19(1):30.

40. Sun JK, Li BB, Shu C, Ma QF, Wang JH. Functions and clinical significance of circular RNAs in glioma. Mol Cancer. 2020;19(1).

\section{Publisher's Note}

Springer Nature remains neutral with regard to jurisdictional claims in published maps and institutional affiliations.

Ready to submit your research? Choose BMC and benefit from:

- fast, convenient online submission

- thorough peer review by experienced researchers in your field

- rapid publication on acceptance

- support for research data, including large and complex data types

- gold Open Access which fosters wider collaboration and increased citations

- maximum visibility for your research: over $100 \mathrm{M}$ website views per year

At $\mathrm{BMC}$, research is always in progress.

Learn more biomedcentral.com/submissions 